\title{
Prevalence of thyroid disease, thyroid dysfunction and thyroid peroxidase antibodies in a large, unselected population. The Health Study of Nord-Trøndelag (HUNT)
}

\author{
T Bjøro ${ }^{1}$, J Holmen ${ }^{3,4}$, Ø Krüger $^{3,4}$, K Midthjell ${ }^{3}$, K Hunstad ${ }^{5}$, T Schreiner ${ }^{2}$, L Sandnes ${ }^{1}$ and H Brochmann ${ }^{6}$ \\ ${ }^{1}$ Hormone Laboratory and ${ }^{2}$ Department of Endocrinology, Aker University Hospital, Oslo, ${ }^{3}$ National Institute of Public Health, Community Medicine \\ Research Unit, Verdal, ${ }^{4}$ Institute of Community Medicine, Norwegian University of Technology and Science, ${ }^{5}$ Stjørdal Health Centre, Stjørdal, and \\ ${ }^{6}$ Naroy Health Centre, Kolvereid, Norway
}

(Correspondence should be addressed to T Bjøro, Hormone Laboratory, Aker University Hospital, N-O514 Oslo, Norway;

Email: trine.bjoro@ioks.uio.no)

\begin{abstract}
Objective: To examine the prevalence of thyroid disease and dysfunction including thyroid autoimmunity in Norway.

Materials and methods: All inhabitants 20 years and older (94 009) in Nord-Trøndelag were invited to participate in a health survey with a questionnaire and blood samples.

Results: The prevalence of former diagnosed hyperthyroidism was $2.5 \%$ in females and $0.6 \%$ in males, hypothyroidism $4.8 \%$ and $0.9 \%$, and goitre $2.9 \%$ and $0.4 \%$ respectively. In both sexes the prevalence increased with age. In individuals without a history of thyroid disease the median, 2.5 and 97.5 percentiles for TSH (mU/l) were 1.80 and $0.49-5.70$ for females and 1.50 and $0.56-4.60$ for males. The TSH values increased with age. When excluding individuals with positive thyroid peroxidase antibodies (TPOAb) $(>200 \mathrm{U} / \mathrm{ml})$, the 97.5 percentiles dropped to $3.60 \mathrm{mU} / \mathrm{l}$ and $3.40 \mathrm{mU} / \mathrm{l}$ respectively. The prevalence of pathological TSH values in females and males were $\mathrm{TSH} \geq 10 \mathrm{mU} / \mathrm{l} 0.90 \%$ and $0.37 \%$; TSH $4.1-9.9 \mathrm{mU} / \mathrm{l} 5.1 \%$ and $3.7 \%$; and $\mathrm{TSH} \leq 0.05 \mathrm{mU} / \mathrm{l} 0.45 \%$ and $0.20 \%$ respectively. The prevalence of positive TPOAb $(>200 \mathrm{U} / \mathrm{ml})$ was $13.9 \%$ in females and $2.8 \%$ in males. In females the lowest percentage $(7.9 \%)$ of positive TPOAb was seen with TSH $0.2-$ $1.9 \mathrm{mU} / \mathrm{l}$ and increased both with lower and higher levels of TSH. The percentage of males with positive TPOAb was lower than in females in all TSH groups except for those with TSH $>10 \mathrm{mU} / \mathrm{l}(85 \%$ TPOAb positive).

Conclusions: In spite of a high prevalence of recognised thyroid disease in the population a considerable number of inhabitants have undiagnosed thyroid dysfunction and also positive TPOAb.
\end{abstract}

European Journal of Endocrinology 143 639-647

\section{Introduction}

Thyroid abnormalities affect a considerable portion of the population (1-3). However, the prevalence and the pattern of thyroid disorders depend on ethnic and geographical factors and especially on iodine intake (4-6). Norway is generally considered to have sufficient iodine-intake $(7,8)$. Norman (9) reported differences in incidences of hypo- and hyperthyroidism in southern and northern parts of Norway. Brochmann et al. (10) reported prevalences of earlier diagnosed and unrecognised hypothyroidism of $3.6 \%$ and $1.8 \%$ respectively, in females over 70 in a small community (Nærøy) in NordTrøndelag (attendance rate 99\%). In Oslo the prevalence of earlier diagnosed hypothyroidism was $4.5 \%$ and unrecognised hypothyroidism was $1 \%$ in females over 70 years (attendance rate $71 \%$ ) (11).

Most prevalence studies of thyroid diseases are small and performed in selected groups of the populations (5, 10, 12, 13). In 1995-1997, a large health study was performed in Nord-Trøndelag County, Norway. A questionnaire included enquiries about thyroid diseases, and blood samples for TSH measurements were drawn from 35576 persons.

In this paper we report the prevalence of earlier diagnosed hyperthyroidism, hypothyroidism and goitre, the treatment given and the prevalence of undiagnosed thyroid dysfunction in persons without known thyroid disease. We also report the prevalence of positive thyroid peroxidase antibodies (TPOAb). 
Table 1 Questions about thyroid illness in the questionnaire.

Have you ever been diagnosed with hyperthyroidism? Have you ever been diagnosed with hypothyroidism? Have you ever been told that you have or have had goitre? Have you ever had a disease in the thyroid gland? Are you or have you been on thyroxine medication? Are you or have you been on Neo-Mercazole medication*? Have you ever had an operation on your thyroid gland? Have you ever been treated with radioactive iodine?

${ }^{*}$ Neo-Mercazole $=$ carbimazole.

\section{Materials and methods}

The study was approved by the regional committee for ethics in medical research and by the Norwegian Data inspectorate.

Nord-Trøndelag is a county in Mid-Norway with 127000 inhabitants. The population is stable with low in- and out-migration. During the period August 1995June 1997 all inhabitants 20-years-old and above (total 94009 ) were invited to participate in the NordTrøndelag Health Study (HUNT). This study was carried out by the National Health Screening service in cooperation with the National Institute of Public Health, Unit for Health Services Research, NordTrøndelag county and the Norwegian University of Science and Technology (NTNU).

In addition to clinical measurements, the participants were asked to complete a three-page self-assessment questionnaire that included eight thyroid-related questions (Table 1). The questionnaire was distributed by mail and returned on arrival at the screening site. Height, weight, blood pressure and hearing were measured in all participants, and spirometry, osteodensimetry and vision were measured in selected subgroups. Venous blood samples were drawn from all participants and analysed for glucose, creatinine and lipids. Thyroid blood tests were carried out in all females, $50 \%$ of males over 40 , and in $5 \%$ of both females and males 20-40 years of age.

\section{Thyroid function tests}

Blood samples were drawn without any restriction regarding eating or time of medication. The thyrotropin (TSH) levels of serum samples were analysed at the Hormone Laboratory, Aker University Hospital. If TSH was $<0.2 \mathrm{mU} / \mathrm{l}$, free thyroxine $\left(\mathrm{fT}_{4}\right)$ and total triiodothyronine $\left(\mathrm{T}_{3}\right)$ were measured in the same sample. If $\mathrm{TSH}>4.0 \mathrm{mU} / \mathrm{l}, \mathrm{fT}_{4}$ and TPOAb were measured. TPOAb were also measured in randomly selected subgroups. The age and TSH values of the subgroups did not differ from the values of the whole group. TSH receptor antibodies (TRAb) were measured in a small subgroup of samples with TSH $<0.05 \mathrm{mU} / \mathrm{l}$.

TSH was measured with DELFIA hTSH Ultra (sensitivity $0.03 \mathrm{mU} / \mathrm{l}$ and total analytical variation $<5 \%$ ),
$\mathrm{fT}_{4}$ with DELFIA free $\mathrm{T}_{4}$ (total analytical variation $<7 \%$ ) and total $\mathrm{T}_{3}$ with AutoDELFIA $\mathrm{T}_{3}$ (total analytical variation $<5 \%$ ), all from Wallac Oy, Turku, Finland. TPOAb were measured with a luminoimmunoassay and TRAb with a radioreceptor assay (bovine TSH receptor), both from B.R.A.H.M.S, Diagnostica $\mathrm{GmbH}$, Berlin, Germany. The sera were stored at $-20^{\circ} \mathrm{C}$.

The laboratory's reference values were TSH $0.2-$ $4.5 \mathrm{mU} / \mathrm{l}, \mathrm{fT}_{4} 8-20 \mathrm{pmol} / \mathrm{l}, \mathrm{T}_{3} 1.2-2.7 \mathrm{nmol} / \mathrm{l}, \mathrm{TPOAb}<$ $200 \mathrm{U} / \mathrm{ml}$ and $\mathrm{TRAb}<10 \mathrm{U} / \mathrm{l}$.

\section{Data analysis}

The data analysis was performed with SPSS (version 8.0). For continuous variables, non-parametric tests (2-tailed Mann-Whitney U tests) were used. Group differences between the number of subjects were analysed using Chi-squared test. $P$ values $<0.05$ were considered statistically significant.

\section{Results}

\section{Population studied}

Of the 94009 persons invited to participate in the study, 46855 (49.8\%) were males and 47254 (50.2\%) were females. In all, 30557 (65.3\%) of the invited males and $34803(73.7 \%)$ of the invited females participated in the study. The youngest and oldest age groups had the lowest attendance rate $(20-29$ years $42 \%$ and $55 \%$, and above 80 years, $48 \%$ and $53 \%$ respectively, for males and females). In persons under 30, a substantial number were resident outside the county because of studies or work but they were still registered as living in Nord-Trøndelag. In the oldest age group, a large number were not able to attend the screening owing to illness or reduced mobility. In the age group 35-75 years, the attendance rates were $75.0 \%$ for males and $83.3 \%$ for females respectively.

\section{Answers to the questionnaire}

Five hundred and sixty-four males (1.8\%) and 3126 females $(8.9 \%)$ (sex ratio females : males 4.9$)$ answered yes to at least one of the thyroid-related questions in the questionnaire (Table 1), indicating a history of thyroid disease or dysfunction; the majority answered yes to more than one of these questions.

Hyperthyroidism In all, $0.6 \%$ of males and $2.5 \%$ of females reported to have hyperthyroidism (sex ratio females : males 4.2). The prevalence increased by age up to the age of 80 (Table 2). For males aged 50-79 years, the prevalence was about $1 \%$, compared with females who had a prevalence between $3.1 \%$ and $3.6 \%$.

The numbers of persons who had either been treated with carbimazole, radioactive iodine or thyroid surgery are shown in Table 2. No participants answered no to all 
Table 2 Self-reported previously diagnosed thyroid disease and treatment.

\begin{tabular}{|c|c|c|c|c|c|c|c|c|c|c|c|c|c|c|c|c|c|}
\hline \multirow{3}{*}{$\begin{array}{l}\text { Age } \\
\text { (years) }\end{array}$} & \multirow{3}{*}{$\begin{array}{c}\text { Total } \\
\text { number* }\end{array}$} & \multicolumn{8}{|c|}{ Diagnosis } & \multicolumn{8}{|c|}{ Treatment } \\
\hline & & \multicolumn{2}{|c|}{ Hyperthyroid } & \multicolumn{2}{|c|}{ Hypothyroid } & \multicolumn{2}{|c|}{ Goitre } & \multicolumn{2}{|c|}{$\begin{array}{c}\text { Thyroid } \\
\text { diseases }\end{array}$} & \multicolumn{2}{|c|}{ Carbimazole } & \multicolumn{2}{|c|}{$\begin{array}{l}\text { Thyroid } \\
\text { surgery }\end{array}$} & \multicolumn{2}{|c|}{$\begin{array}{l}\text { Radioactive } \\
\text { iodine }\end{array}$} & \multicolumn{2}{|c|}{ Thyroxine } \\
\hline & & $n$ & $\%$ & $n$ & $\%$ & $n$ & $\%$ & $n$ & $\%$ & $n$ & $\%$ & $n$ & $\%$ & $n$ & $\%$ & $n$ & $\%$ \\
\hline \multicolumn{18}{|l|}{ Males } \\
\hline 20-29 & 4325 & 7 & 0.16 & 14 & 0.32 & 2 & 0.05 & 4 & 0.09 & 2 & 0.05 & 2 & 0.05 & 3 & 0.07 & 10 & 0.23 \\
\hline $30-39$ & 5503 & 12 & 0.22 & 25 & 0.45 & 9 & 0.16 & 5 & 0.09 & 0 & 0.00 & 5 & 0.09 & 3 & 0.05 & 21 & 0.38 \\
\hline $40-49$ & 6581 & 28 & 0.43 & 51 & 0.77 & 19 & 0.29 & 12 & 0.18 & 7 & 0.11 & 16 & 0.24 & 19 & 0.29 & 44 & 0.67 \\
\hline $50-59$ & 5143 & 44 & 0.86 & 34 & 0.66 & 24 & 0.47 & 27 & 0.52 & 2 & 0.04 & 26 & 0.51 & 20 & 0.39 & 49 & 0.95 \\
\hline $60-69$ & 4340 & 44 & 1.01 & 70 & 1.61 & 27 & 0.62 & 20 & 0.46 & 7 & 0.16 & 34 & 0.78 & 27 & 0.62 & 86 & 1.98 \\
\hline $70-79$ & 3537 & 37 & 1.05 & 56 & 1.58 & 23 & 0.65 & 12 & 0.34 & 1 & 0.03 & 27 & 0.76 & 18 & 0.51 & 73 & 2.06 \\
\hline$\geq 80$ & 1090 & 6 & 0.55 & 21 & 1.93 & 8 & 0.73 & 1 & 0.09 & 1 & 0.09 & 10 & 0.92 & 4 & 0.37 & 20 & 1.83 \\
\hline $\begin{array}{l}\text { All } \\
\text { Females }\end{array}$ & 30519 & 178 & 0.58 & 271 & 0.89 & 112 & 0.37 & 81 & 0.27 & 20 & 0.07 & 120 & 0.39 & 94 & 0.31 & 303 & 0.99 \\
\hline $20-29$ & 5188 & 51 & 0.98 & 80 & 1.54 & 30 & 0.58 & 11 & 0.21 & 8 & 0.15 & 6 & 0.12 & 11 & 0.21 & 48 & 0.93 \\
\hline $30-39$ & 6251 & 93 & 1.49 & 175 & 2.80 & 110 & 1.76 & 39 & 0.62 & 21 & 0.34 & 32 & 0.51 & 32 & 0.51 & 128 & 2.05 \\
\hline $40-49$ & 7089 & 160 & 2.26 & 313 & 4.42 & 184 & 2.60 & 77 & 1.09 & 22 & 0.31 & 105 & 1.48 & 75 & 1.06 & 300 & 4.23 \\
\hline $50-59$ & 5538 & 170 & 3.07 & 373 & 6.74 & 183 & 3.30 & 86 & 1.55 & 18 & 0.33 & 151 & 2.73 & 99 & 1.79 & 395 & 7.13 \\
\hline $60-69$ & 4708 & 171 & 3.63 & 354 & 7.52 & 206 & 4.38 & 63 & 1.34 & 10 & 0.21 & 143 & 3.04 & 92 & 1.95 & 398 & 8.45 \\
\hline $70-79$ & 4282 & 155 & 3.62 & 281 & 6.56 & 214 & 5.00 & 42 & 0.98 & 10 & 0.23 & 132 & 3.08 & 61 & 1.42 & 356 & 8.31 \\
\hline$\geq 80$ & 1688 & 56 & 3.32 & 90 & 5.33 & 76 & 4.50 & 10 & 0.59 & 3 & 0.18 & 46 & 2.73 & 24 & 1.42 & 115 & 6.81 \\
\hline All & 34744 & 856 & 2.46 & 1666 & 4.80 & 1003 & 2.89 & 328 & 0.94 & 92 & 0.26 & 615 & 1.77 & 394 & 1.13 & 1740 & 5.01 \\
\hline
\end{tabular}

Percentages of males and females who answered yes to the questions in Table 1.

* Total number who attended the health survey and returned the questionnaire.

** Thyroid diseases including thyroid cancer, thyroiditis but also other thyroid disorders (see text).

three questions regarding treatment; however, 47 males $(26 \%)$ and 172 females $(20 \%)$ did not answer yes to any of these questions.

Hypothyroidism The prevalence of hypothyroidism was $0.9 \%$ and $4.8 \%$ for males and females respectively (sex ratio females : males 5.4 ). Only $1.5 \%$ of females under 30 were, or had been, hypothyroidic, compared with $7.5 \%$ of those in their seventh decade. However in the oldest group (females over 80) the prevalence decreased. In males, the prevalence of hypothyroidism increased by age also in the oldest (Table 2).

The number of participants on current or former thyroxine medication is shown in Table 2. However, 219 out of the 271 hypothyroid males $(81 \%)$ reported current or former thyroxine medication and 1349 of 1666 females $(81 \%)$.

Goitre The prevalence of self-reported goitre was 2.9\% in females. In the youngest group, the prevalence was only $0.6 \%$ compared with almost $5 \%$ in the oldest age groups. In males, the prevalence was only $0.4 \%$, and increased with age (Table 2).

Thyroid diseases A total of 328 females (1.0\%) and 81 $(0.3 \%)$ males answered yes to this question, but only 176 females $(0.5 \%)$ and 48 males $(0.2 \%)$ also answered no to the questions about goitre, hypo- and hyperthyroidism. This group included persons treated for nodules, cancer or thyroiditis.

\section{Thyroid function tests in persons without former or present thyroid disease}

Reference range for TSH In calculating the reference ranges for TSH, the results from persons (9754 males and 19327 females) answering no to all questions about thyroid disease (Table 1) and diabetes mellitus were included.

Table 3 shows the median, 2.5 and 97.5 percentiles for TSH, all increasing with age. Regardless of age, the 2.5 and 97.5 percentiles were $0.56-4.60 \mathrm{mU} / \mathrm{l}$ for males and $0.49-5.70 \mathrm{mU} / \mathrm{l}$ for females. The TSH value was significantly lower in males than in females $(P<0.001)$ and increased with age.

TPOAb was measured in samples with TSH $>4.0 \mathrm{mU} / \mathrm{l}$ (1082 females and 370 males) and in randomly selected samples from females $(n=582)$ and males $(n=360)$ without a history of thyroid disease (see below). The median, 2.5 and 97.5 percentiles for TSH were recalculated after excluding persons known to have TPOAb $>200 \mathrm{U} / \mathrm{ml}$ even though $\mathrm{TPOAb}$ was measured only in a small percentage $(2.5 \%)$ of the samples with $\mathrm{TSH}<4.0 \mathrm{mU} / \mathrm{l}$. In males, the median and 2.5 percentile for TSH did not change, while the 97.5 percentile dropped from 4.60 to $3.40 \mathrm{mU} / \mathrm{l}$. The TSH values in males without positive TPOAb were significantly lower than in males regardless of TPOAb value in all age groups except for those below 40 years $(P<0.001$ for those over 40 years and $P=0.085$ for those below 40 years). In females the median and 2.5 percentile marginally decreased, whereas the 97.5 percentile 
Table 3 TSH - median, 2.5 and 97.5 percentiles in persons without known thyroid disease or diabetes.

\begin{tabular}{|c|c|c|c|c|c|c|c|c|}
\hline \multirow[b]{2}{*}{ Age } & \multicolumn{4}{|c|}{ Regardless of TPOAb value } & \multicolumn{4}{|c|}{ Without positive TPOAb } \\
\hline & Number & Median* & $2.5 \%$ & $97.5 \%$ & Number & Median* $^{*}$ & $2.5 \%$ & $97.5 \%$ \\
\hline \multicolumn{9}{|l|}{ Males } \\
\hline$<40$ & 459 & 1.40 & 0.50 & 4.05 & 441 & 1.40 & 0.50 & 3.40 \\
\hline $40-49$ & 3049 & 1.40 & 0.54 & 3.90 & 2899 & 1.40 & 0.54 & 3.30 \\
\hline $50-59$ & 2398 & 1.50 & 0.56 & 4.10 & 2257 & 1.50 & 0.56 & 3.30 \\
\hline $60-69$ & 1986 & 1.60 & 0.59 & 4.73 & 1849 & 1.50 & 0.59 & 3.50 \\
\hline $70-79$ & 1454 & 1.70 & 0.58 & 5.56 & 1322 & 1.60 & 0.58 & 3.50 \\
\hline$\geq 80$ & 388 & 1.90 & 0.60 & 6.70 & 349 & 1.80 & 0.59 & 3.80 \\
\hline All & 9754 & 1.50 & 0.56 & 4.60 & 9130 & 1.50 & 0.56 & 3.40 \\
\hline \multicolumn{9}{|l|}{ Females } \\
\hline$<40$ & 540 & 1.40 & 0.37 & 5.09 & 514 & 1.30 & 0.37 & 3.30 \\
\hline $40-49$ & 6241 & 1.50 & 0.52 & 4.90 & 5845 & 1.40 & 0.53 & 3.40 \\
\hline $50-59$ & 4591 & 1.60 & 0.51 & 5.30 & 4256 & 1.50 & 0.50 & 3.60 \\
\hline $60-69$ & 3712 & 1.70 & 0.51 & 6.92 & 3380 & 1.60 & 0.49 & 3.60 \\
\hline $70-79$ & 3158 & 1.70 & 0.42 & 6.60 & 2857 & 1.70 & 0.39 & 3.70 \\
\hline$\geq 80$ & 1019 & 1.80 & 0.37 & 6.40 & 916 & 1.70 & 0.36 & 3.80 \\
\hline All & 19327 & 1.60 & 0.49 & 5.70 & 17824 & 1.50 & 0.48 & 3.60 \\
\hline
\end{tabular}

${ }^{*} \mathrm{TSH}$ values above $1.0 \mathrm{mU} / \mathrm{l}$ were reported with only one decimal.

decreased from 5.70 to $3.60 \mathrm{mU} / \mathrm{l}$. In all age groups, TSH was significantly lower in females without positive TPOAb $(P<0.001)$.

Biochemical hypothyroidism The prevalence of $\mathrm{TSH} \geq 10 \mathrm{mU} / \mathrm{l}$ was $0.37 \%$ in males and $0.90 \%$ in females without former or present thyroid disease (Table 4 ). Only $37 \%$ of males and $56 \%$ of females with $\mathrm{TSH} \geq 10 \mathrm{mU} / \mathrm{l}$ also had $\mathrm{fT}_{4}$ below $8.0 \mathrm{pmol} / \mathrm{l}$ (i.e. below the reference range); however, up to $92 \%$ and $97 \%$ respectively, had $\mathrm{fT}_{4}<12 \mathrm{pmol} / \mathrm{l}$ (i.e. low or low normal
$\mathrm{fT}_{4}$ values). In females the highest prevalence of biochemical hypothyroidism was in those aged 60-69 years $(1.24 \%)$ and lowest in those aged $40-49$ years $(0.63 \%)$.

A TSH value between 4.0 and $10 \mathrm{mU} / \mathrm{l}$ was present in $3.7 \%$ of the males and $5.1 \%$ of the females, and $2.2 \%$ and $5.1 \%$ respectively (or $0.08 \%$ and $0.26 \%$ of the total) simultaneously had $\mathrm{fT}_{4}$ values below $8.0 \mathrm{pmol} / \mathrm{l}$, whereas $63 \%$ of males and $76 \%$ of females with TSH levels between 4.0 and $10 \mathrm{mU} / \mathrm{l}$ had $\mathrm{fT}_{4}$ values below $12.0 \mathrm{pmol} / \mathrm{l}$ (Table 4).

Table 4 Prevalence of biochemical hypothyroidism in persons without former or present thyroid disease. A) Defined as TSH $\geq 10 \mathrm{mU} / \mathrm{l}$ and B) defined as $\mathrm{TSH}>4$ and $<10 \mathrm{mU} / \mathrm{l}$.

\section{A) $\mathrm{TSH} \geq 10 \mathrm{mU} / \mathrm{l}$}

\begin{tabular}{|c|c|c|c|c|c|c|c|c|c|c|c|c|c|c|c|c|c|}
\hline \multirow[b]{2}{*}{ Age } & \multirow{2}{*}{$\begin{array}{c}\text { Total } \\
\text { number }\end{array}$} & \multicolumn{2}{|c|}{ All } & \multicolumn{2}{|c|}{$\& \mathrm{FT}_{4}<8.0$} & \multicolumn{2}{|c|}{$\& \mathrm{FT}_{4}<12.0$} & \multicolumn{2}{|c|}{$\begin{array}{c}\& \text { TPOAb }> \\
200\end{array}$} & \multicolumn{2}{|c|}{ All } & \multicolumn{2}{|c|}{$\& \mathrm{FT}_{4}<8.0$} & \multicolumn{2}{|c|}{$\& \mathrm{FT}_{4}<12.0$} & \multicolumn{2}{|c|}{$\begin{array}{c}\& \text { TPOAb }> \\
200\end{array}$} \\
\hline & & $n$ & $\%^{1}$ & $n$ & $\%^{2}$ & $n$ & $\%^{2}$ & $n$ & $\%^{2}$ & $n$ & $\%^{1}$ & $n$ & $\%^{3}$ & $n$ & $\%^{3}$ & $n$ & $\%^{3}$ \\
\hline \multicolumn{18}{|l|}{ Males } \\
\hline$<40$ & 460 & 1 & 0.22 & 1 & 100 & 1 & 100 & 1 & 100 & 11 & 2.4 & 0 & 0.0 & 5 & 46 & 2 & 18 \\
\hline $40-49$ & 3096 & 14 & 0.45 & 5 & 36 & 13 & 93 & 14 & 100 & 60 & 1.9 & 1 & 1.7 & 37 & 62 & 19 & 32 \\
\hline $50-59$ & 2474 & 8 & 0.32 & 2 & 25 & 7 & 88 & 5 & 63 & 60 & 2.4 & 2 & 3.3 & 38 & 63 & 24 & 40 \\
\hline $60-69$ & 2094 & 5 & 0.24 & 2 & 40 & 5 & 100 & 4 & 80 & 93 & 4.4 & 4 & 4.3 & 63 & 68 & 24 & 26 \\
\hline $70-79$ & 1588 & 8 & 0.50 & 3 & 38 & 7 & 88 & 8 & 100 & 97 & 6.1 & 1 & 1.0 & 67 & 69 & 20 & 21 \\
\hline$\geq 80$ & 453 & 2 & 0.44 & 1 & 50 & 2 & 100 & 1 & 50 & 51 & 11.3 & & 0.0 & 23 & 45 & 8 & 16 \\
\hline All & 10165 & 38 & 0.37 & 14 & 37 & 35 & 92 & 33 & 87 & 372 & 3.7 & 8 & 2.2 & 233 & 63 & 97 & 26 \\
\hline \multicolumn{18}{|c|}{ Females } \\
\hline$<40$ & 542 & 5 & 0.92 & 4 & 80 & 5 & 100 & 4 & 80 & 13 & 2.4 & 2 & 15.4 & 13 & 100 & 7 & 54 \\
\hline $40-49$ & 6309 & 40 & 0.63 & 18 & 45 & 40 & 100 & 35 & 88 & 231 & 3.7 & 10 & 4.3 & 176 & 76 & 137 & 59 \\
\hline $50-59$ & 4697 & 37 & 0.79 & 21 & 57 & 36 & 97 & 31 & 84 & 218 & 4.6 & 11 & 5.0 & 175 & 80 & 110 & 51 \\
\hline $60-69$ & 3881 & 48 & 1.24 & 33 & 69 & 47 & 98 & 41 & 85 & 229 & 5.9 & 19 & 8.3 & 177 & 77 & 101 & 44 \\
\hline $70-79$ & 3479 & 38 & 1.09 & 20 & 53 & 36 & 95 & 32 & 84 & 227 & 6.5 & 9 & 4.0 & 161 & 71 & 98 & 43 \\
\hline$\geq 80$ & 1224 & 14 & 1.14 & 6 & 43 & 13 & 93 & 11 & 79 & 101 & 8.3 & 1 & 1.0 & 71 & 70 & 34 & 34 \\
\hline All & 20132 & 182 & 0.90 & 102 & 56 & 177 & 97 & 154 & 85 & 1019 & 5.1 & 52 & 5.1 & 773 & 76 & 487 & 48 \\
\hline
\end{tabular}

\footnotetext{
$1 \%$ of total number; ${ }^{2} \%$ of number with $\mathrm{TSH} \geq 10 \mathrm{mU} / \mathrm{l} ;{ }^{3} \%$ of number with $\mathrm{TSH} \geq 4$ and $<10 \mathrm{mU} / \mathrm{l}$.
} 
Table 5 Prevalence of biochemical hyperthyroidism in persons without former or present thyroid diseases. A) Defined as TSH $\leq 0.05 \mathrm{mU} / \mathrm{l}$ and $\mathrm{B}$ ) defined as $\mathrm{TSH}>0.05$ and $<0.2 \mathrm{mU} / \mathrm{l}$.

\begin{tabular}{|c|c|c|c|c|c|c|c|c|c|}
\hline \multirow[b]{3}{*}{ Age } & \multirow{3}{*}{$\begin{array}{c}\text { Total } \\
\text { number }\end{array}$} & \multicolumn{4}{|c|}{ A) $\mathrm{TSH} \leq 0.05 \mathrm{mU} / \mathrm{l}$} & \multicolumn{4}{|c|}{ B) $\mathrm{TSH}>0.05$ and $<0.2 \mathrm{mU} / \mathrm{l}$} \\
\hline & & \multirow[b]{2}{*}{$n$} & \multirow[b]{2}{*}{$\%^{1}$} & \multicolumn{2}{|c|}{$\& \mathrm{FT}_{4}>20$ or $\mathrm{T}_{3}>2.8$} & \multirow[b]{2}{*}{$n$} & \multirow[b]{2}{*}{$\%^{1}$} & \multicolumn{2}{|c|}{$\& \mathrm{FT}_{4}>20$ or $\mathrm{T}_{3}>2.8$} \\
\hline & & & & $n$ & $\%^{2}$ & & & $n$ & $\%^{3}$ \\
\hline \multicolumn{10}{|l|}{ Males } \\
\hline$<40$ & 460 & 0 & 0.00 & 0 & 0 & 1 & 0.22 & 0 & 0 \\
\hline $40-49$ & 3096 & 1 & 0.03 & 1 & 100 & 1 & 0.03 & 0 & 0 \\
\hline $50-59$ & 2474 & 2 & 0.08 & 1 & 50 & 1 & 0.04 & 0 & 0 \\
\hline $60-69$ & 2094 & 1 & 0.05 & 0 & 0 & 4 & 0.19 & 2 & 50 \\
\hline $70-79$ & 1588 & 3 & 0.19 & 1 & 33 & 4 & 0.25 & 1 & 25 \\
\hline$\geq 80$ & 453 & 2 & 0.44 & 1 & 50 & 0 & 0.00 & 0 & 0 \\
\hline All & 10165 & 9 & 0.09 & 4 & 44 & 11 & 0.11 & 3 & 27 \\
\hline \multicolumn{10}{|c|}{ Females } \\
\hline$<40$ & 542 & 3 & 0.55 & 1 & 33 & 3 & 0.55 & 1 & 33 \\
\hline $40-49$ & 6309 & 26 & 0.41 & 17 & 65 & 13 & 0.21 & 1 & 8 \\
\hline $50-59$ & 4697 & 21 & 0.45 & 11 & 52 & 4 & 0.09 & 0 & 0 \\
\hline $60-69$ & 3881 & 14 & 0.36 & 7 & 50 & 15 & 0.39 & 2 & 13 \\
\hline $70-79$ & 3479 & 19 & 0.55 & 12 & 63 & 23 & 0.66 & 4 & 17 \\
\hline$\geq 80$ & 1224 & 10 & 0.82 & 7 & 70 & 8 & 0.65 & 1 & 13 \\
\hline All & 20132 & 93 & 0.46 & 55 & 59 & 66 & 0.33 & 9 & 14 \\
\hline
\end{tabular}

$1 \%$ of total number; ${ }^{2} \%$ of number with TSH $\leq 0.05 \mathrm{mU} / \mathrm{l} ;{ }^{3} \%$ of number with $\mathrm{TSH}>0.05$ and $<0.2 \mathrm{mU} / \mathrm{l}$.

Biochemical hyperthyroidism The prevalence of suppressed TSH $(\leq 0.05 \mathrm{mU} / \mathrm{l})$ was $0.09 \%$ in males and $0.46 \%$ in females (Table 5). Four of nine males $(44 \%)$ and 55 of 93 females (59\%) with suppressed TSH also had elevated $\mathrm{fT}_{4}(>20 \mathrm{pmol} / \mathrm{l})$ and/or elevated $\mathrm{T}_{3}$ $(>2.8 \mathrm{nmol} / \mathrm{l})$ values.

TSH values between 0.05 and $0.2 \mathrm{mU} / \mathrm{l}$ were found in $0.11 \%$ of males and $0.33 \%$ of females respectively. However, 3 of 11 males $(27 \%)$ and 9 of 66 females $(14 \%)$ also had elevated $\mathrm{fT}_{4}$ and/or $\mathrm{T}_{3}$. The prevalence of low TSH $(>0.05 \mathrm{mU} / \mathrm{l}$ but $<0.2 \mathrm{mU} / \mathrm{l})$ in combination with elevated $\mathrm{fT}_{4}$ and/or $\mathrm{T}_{3}$ was $0.03 \%$ in males and $0.05 \%$ in females.

Thyroid antibodies The prevalence of positive TPOAb $(>200 \mathrm{U} / \mathrm{ml})$ in a randomly selected subgroup of females $(n=582)$ and males $(n=360)$ aged over 40 without current or former thyroid diseases was $13.9 \%$ and $2.8 \%$ respectively (females compared with males, $P<0.001$ ). The prevalence of positive TPOAb did not change significantly with age in these individuals $(P=0.55)$.

The TSH values were significantly higher in patients with positive TPOAb than in those with negative antibodies. Median TSH for TPOAb negative females was $1.5 \mathrm{mU} / \mathrm{l}$ and $2.5 \mathrm{mU} / \mathrm{l}$ for those with positive TPOAb $(P<0.001)$ and $1.5 \mathrm{mU} / \mathrm{l}$ and $3.5 \mathrm{mU} / \mathrm{l}$ respectively for males $(P<0.001)$. The percentage of elevated $\mathrm{TSH}(>4 \mathrm{mU} / \mathrm{l})$ in TPOAb positive females was $24.0 \%$ and $2.4 \%$ in TPOAb negative females $(P<0.001)$, and $6.0 \%$ in the total group. In TPOAb positive males, TSH was elevated in $40.0 \%$ whereas it was only increased in $3.5 \%$ in TPOAb negative males $(P<0.001)$.

The prevalence of positive TPOAb changed with TSH values (Fig. 1). The lowest prevalence was seen in the group with $\mathrm{TSH} \geq 0.2 \mathrm{mU} / \mathrm{l}$ but $\leq 2.0 \mathrm{mU} / \mathrm{l}$, whereas only $7.6 \%$ of the females and none of the 197 males with measured TPOAb had positive antibodies. A small increase in TSH values $(>2.0 \mathrm{mU} / \mathrm{l}$ but $\leq 4.0 \mathrm{mU} / \mathrm{l})$ more than doubled the percentage of positive TPOAb, $19.7 \%$ in females and $6.9 \%$ in males. The percentage with positive TPOAb increased with TSH both in females and males. Up to $85.6 \%$ of the females and $87 \%$ of males with $\mathrm{TSH}>10 \mathrm{mU} / \mathrm{l}$ had positive TPOAb.

The percentage of positive TPOAb also increased with low TSH; $16.7 \%$ of males and $34.7 \%$ of females with $\mathrm{TSH}<0.2 \mathrm{mU} / \mathrm{l}$ were TPOAb positive.

The percentage of males with positive TPOAb was lower than in females in all age groups except for those with TSH > $10 \mathrm{mU} / \mathrm{l}$ (Fig. 1).

About $70 \%$ (males $68.6 \%$ and females $74.4 \%$ ) of the persons with positive TPOAb had values $>1000 \mathrm{U} / \mathrm{ml}$ and approximately $10 \%$ (males $11.7 \%$ and females $8.5 \%$ ) had TPOAb values between 200 and $400 \mathrm{U} / \mathrm{ml}$. This tendency was independent of age (4079 years).

TRAb and TPOAb were measured in a subgroup of females with $\mathrm{TSH}<0.05 \mathrm{mU} / \mathrm{ml}$ and $27 \%$ had both positive TRAb and TPOAb. A few had only positive TPOAb $(1.2 \%)$ and none of the patients were only TRAb positive.

\section{Discussion}

Nearly $9 \%$ of females and $2 \%$ of males over the age of 20 had a previously diagnosed thyroid disorder. Hypothyroidism had been diagnosed in $4.8 \%$ of females and $0.9 \%$ of the males. The TSH screening revealed unrecognised biochemical hypothyroidism $(\mathrm{TSH} \geq 10 \mathrm{mU} / \mathrm{l})$ in $0.9 \%$ 


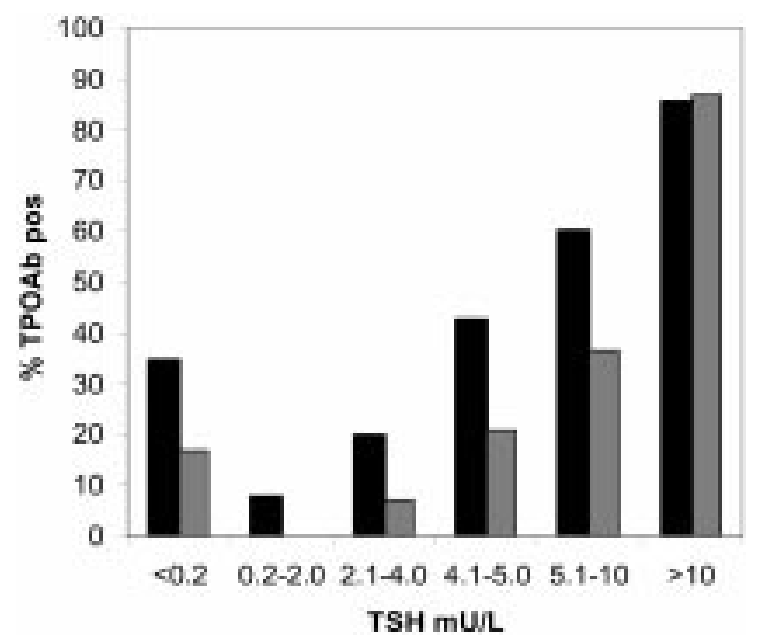

Figure 1 Percentage positive TPOAb at different TSH values in males (shaded bars) and females (solid bars) without known thyroid disease. TPOAb was measured in all blood samples with $\mathrm{TSH}>4 \mathrm{mU} / \mathrm{l}$ and in randomly selected subgroups with $\mathrm{TSH}<$ $4 \mathrm{mU} / \mathrm{l}$. The number of samples with measured TPOAb was $\mathrm{TSH}<0.2 \mathrm{mU} / \mathrm{l}$, males $n=30$, females $n=49$; TSH $0.2-2.0 \mathrm{mU} / \mathrm{l}$, males $n=197$, females $n=315$; TSH 2.1-4.0 $\mathrm{mU} / \mathrm{l}$, males $n=72$, females $n=117$; TSH 4.1-5.0 mU/l, males $n=183$, females $n=446$; TSH $5.1-10.0 \mathrm{mU} / \mathrm{l}$, males $n=161$, females $n=493$; TSH $>10 \mathrm{mU} / \mathrm{l}$, males $n=38$, females $n=180$.

of females and $0.4 \%$ of males, and moderately elevated TSH (4.0-9.9 mU/l) in 5.1\% of females and $3.7 \%$ of males. Hyperthyroidism had been diagnosed in $2.5 \%$ of females and in $0.6 \%$ of males. The TSH screening revealed unrecognised biochemical hyperthyroidism $(\mathrm{TSH} \leq 0.05 \mathrm{mU} / \mathrm{l})$ in $0.5 \%$ of females and in $0.1 \%$ of males and moderately suppressed TSH $(0.05-0.19 \mathrm{mU} / \mathrm{l})$ in $0.3 \%$ and $0.1 \%$ respectively. Goitre was reported in $2.9 \%$ of females and $0.4 \%$ in males.

The strength of our study was the very large number of participants from an unselected population, the large age range, with no upper age limits, and the high attendance rate, especially in the age group aged 35-80. In those over 80, the attendance rate was lower, which might explain the lower prevalence of all types of thyroid disorders in this group. However, when comparing results from different areas, the results might be influenced by various treatment traditions and diagnostic criteria.

\section{Hyperthyroidism}

The prevalence of previously diagnosed hyperthyroidism in the present study was lower than previously reported from Great Britain (14) for females (2.5\% vs. $3.7 \%$ ). However, the prevalence of unknown hyperthyroidism is similar to that reported from the UK (14) but somewhat higher than in Sweden (13), and lower than in Denmark (5).

\section{Hypothyroidism}

The prevalence of previously diagnosed hypothyroidism was higher in males (0.9\%) and lower in females $(4.8 \%)$ than reported by Vandepump et al. (14) (0.5\% and 7.1\% respectively). The prevalence of unrecognised hypothyroidism was higher in both females and males compared with the reports from Sweden and the UK. However, most of the unrecognised hypothyroidism was mild to moderate. Compared with the data reported by Brochmann et al. (10), the prevalence of former diagnosed hypothyroidism in females over 70 years of age in Nærøy had increased $(3.5 \%$ vs. $6.2 \%$ reported in this study). Comparing the prevalence of undiagnosed hypothyroidism is difficult owing to the different diagnostic criteria used. Brochmann et al. (10) reported a prevalence of $\mathrm{TSH}>6 \mathrm{mU} / \mathrm{l}$ of $5.2 \%$ in females and $3.5 \%$ in males over 70 in Nærøy. The prevalence of $\mathrm{TSH}>6 \mathrm{mU} / \mathrm{l}$ was exactly the same in our study (data not shown).

A recent report from Colorado stated a prevalence of elevated TSH $(>5.1 \mathrm{mU} / \mathrm{l})$ of $9.5 \%$ in the adult population increasing with age from 3 to $16 \%$ in males and from 4 to $21 \%$ in females (3). The prevalence of elevated TSH in the Colorado study was almost twice the prevalence we observed $(5.3 \%$ of the total population in our study) even though we used a lower cut-off value $(\mathrm{TSH}>4.0 \mathrm{mU} / \mathrm{l}$ vs. $>5.1 \mathrm{mU} / \mathrm{l})$. Also in the Rotterdam study (15), the prevalence of elevated TSH was higher (11\% of elderly females over 55 years of age had subclinical hypothyroidism). The classic study of Sawin et al. (2) reported a higher prevalence of elevated TSH ( $13 \%$ of the females over 60 years of age); however, there is no information regarding former diagnosed thyroid disorders in this report. In our study, the prevalence data of abnormal TSH values is from subjects without former thyroid disorders or use of thyroxine. From Italy, Rivolta et al. (16) recently reported a similar prevalence of subclinical hypothyroidism to the present study.

The prevalence of moderately elevated TSH (4.1$9.9 \mathrm{mU} / \mathrm{l}$ ) was substantially higher in both males and females over 80 compared with the younger age groups, whereas the prevalence of markedly elevated TSH $(\geq 10 \mathrm{mU} / \mathrm{l})$ was higher in the younger age groups. This might be explained by the more frequent need of medical care with increased age, including more frequent TSH measurements.

Our results demonstrate that thyroid dysfunction may develop gradually. Using the established reference values for $\mathrm{fT}_{4}$ only a small fraction had $\mathrm{fT}_{4}$ values below the normal range; however, the majority had $\mathrm{fT}_{4}$ in the lower normal range. This finding corresponds well to what Bauer \& Brown (17) reported in outpatients. The negative correlation between $\mathrm{fT}_{4}$ and TSH is well known and the reported results also focus on the difficulties in establishing 'reference values'. A considerable portion of those with low $\mathrm{TSH}$ had $\mathrm{fT}_{4}$ and $\mathrm{T}_{3}$ values within the 
normal range, but this could also be due to a nonthyroid-related illness.

\section{Goitre}

The prevalence of goitre in those aged $60-69$ was $4.4 \%$ in females and $0.6 \%$ in males, compared with $12.2 \%$ and $3.2 \%$ respectively in Jutland and $1.9 \%$ and $2.2 \%$ in Iceland (5).

This age group in our study showed a higher prevalence of undiagnosed hyperthyroidism than in Iceland, but far lower than in Jutland (5). Ten per cent of females in Jutland had TSH below $0.4 \mathrm{mU} / \mathrm{l}$ whereas this was less than $2.5 \%$ in Nord-Trøndelag. The prevalence of elevated TSH was high in Iceland, and approximately $18 \%$ of females in their sixties had TSH above $4 \mathrm{mU} / \mathrm{l}$, but only $7.1 \%$ in Norway and 3.8\% in Jutland. Both the goitre data and the TSH values indicate that the pattern of thyroid disorders is between those found in Iceland (high iodine intake area) and Jutland (low iodine intake area). We do not have recent data for iodine intake in Nord-Trøndelag; however, Kapelrud et al. (8) reported an iodine intake of about $200 \mu \mathrm{g} / 24 \mathrm{~h}$ in six different communities in Norway. Laurberg et al. (5) concluded that both high and low iodine intake levels correlated to high prevalence rate of thyroid abnormalities (although the pattern of abnormalities differ). They speculate that a window in iodine intake level might exist where thyroid disorders are less common. Mild iodine deficiency may partly protect against autoimmune thyroid disease, as reported for several animal strains (18).

The prevalence of spontaneous hypothyroidism (TSH $\geq 10 \mathrm{mU} / \mathrm{l}$ ) of $0.9 \%$ in females and $0.4 \%$ in males in our cross-sectional study is somewhat higher than expected from the mean incident rate for hypothyroidism in females of $0.35 \%$ per year and $0.06 \%$ per year in males reported by Vanderpump et al. (14). Also, our reported prevalence of undiagnosed hyperthyroidism $(0.5 \%$ in females and $0.1 \%$ in males) is higher than expected from the mean incident rate for hyperthyroidism in females of $0.08 \%$ per year and the negligible incident rate in males (14).

The prevalence data of former diagnosed thyroid disease is based on questionnaires. Similar questions were used in the Nærøy study (10) and the answers were then compared with the medical records and showed a good correlation. Furthermore, the percentage of patients answering yes to questions about treatment corresponds to the prevalence of thyroid disease. Surprisingly, only $81 \%$ of those who reported former or present hypothyroidism also confirmed present or former thyroxine medication. However, none of those who answered yes to present or former hypothyroidism also answered no to former or present thyroxine medication.

In 19971.16 million dosages of $0.1 \mathrm{mg}$ thyroxine were sold in Nord-Trøndelag (information from Norsk Medisinaldepot A/S). The average daily dosage is estimated to be $0.1-0.125 \mathrm{mg}$. Assuming the number of persons under 20 on thyroxine medication is negligible, then between $2.6 \%$ (if the daily dosage is $0.125 \mathrm{mg}$ ) and $3.3 \%$ (if the daily dosage is $0.1 \mathrm{mg}$ ) of the total population over 20 years used thyroxine. This is in accordance with the $3 \%$ of the population reporting former or current $\mathrm{T}_{4}$ medication.

Nearly $80 \%$ of those with a history of hyperthyroidism answered yes to one or more of three questions on treatment of hyperthyroidism. Few patients reported carbimazole treatment but nearly $20 \%$ had not answered all the treatment questions.

Both overt hyper- and hypothyroidism have a variety of adverse effects and should be treated. However, diagnosing and treatment of subclinical or biochemical thyroid dysfunction remains controversial. Subclinical hyperthyroidism is a risk factor for atrial fibrillation at least in older persons (19) and approximately 10-15\% of patients with overt hyperthyroidism, who have atrial fibrillation will have an atrial embolic event $(20,21)$. At least older persons with low TSH should be monitored regarding overt hyperthyroidism and/or atrial fibrillation. In persons with subclinical hypothyroidism the lipid profiles did not differ from the control groups for those with moderately elevated TSH values, but when analysed according to the severity of the subclinical hypothyroidism (TSH $\geq 10 \mathrm{mU} / \mathrm{l})$, the data showed increases in serum total- and LDL-cholesterol and decreases in serum HDL-cholesterol $(22,23)$. The unfavourable lipid profile can be reversed by thyroxine therapy (24-27). Whether thyroxine treatment of subclinical hypothyroidism reduces the risk of coronary heart disease has not been demonstrated.

A recent report from The Netherlands demonstrates that subclinical hypothyroidism is a strong indicator of risk for atherosclerosis and myocardial infarction in elderly females (15).

Observation suggests that subclinical hypothyroidism lowers the threshold for the development of major depressive disorders and modifies its clinical features $(28-30)$. Still, controlled studies of thyroxine treatment are lacking.

Nyström et al. (31) reported that $25 \%$ of middle-aged and old women with subclinical hypothyroidism would benefit from thyroxine medication. The threshold for measuring TSH, at least in these females, should be low because the prevalence of thyroid dysfunction is high.

We have no definitive information on the nature of hyperfunction of the thyroid gland except in a subgroup revealing $27 \%$ of the females with TSH $\leq 0.05$ as TRAb positive. We also report that about $17 \%$ of males and $35 \%$ of females without former diagnosed thyroid diseases and with TSH $<0.2$ were TPOAb positive. Our study demonstrates that the large majority of females and males with hypothyroidism were TPOAb positive. This indicates that autoimmunity is an important factor in both hyper- and hypothyroidism in Norway. Nord-Trøndelag is fairly representative of Norway as a whole $(32,33)$. 
Positive TPOAb were found in $2.8 \%$ of males and $13.9 \%$ of females over 40 years of age and no difference between the age groups was observed. The prevalence was also lower in both sexes compared with that reported in Norwegian blood donors (34). In the present study we have prevalence data only for TPOAb in persons over 40 years of age. We reported a higher prevalence of positive thyroid antibodies in females over 45 years compared with those under 45 years (34). This might indicate that TPOAb appears in the circulation long before the change of thyroid function can be observed by changes in the TSH values.

It is interesting to note that both the sex and age differences in median TSH, and 97.5 percentile disappeared when the TPOAb positive persons were excluded. The higher prevalence of TPOAb in females than in males explains the higher TSH values in females. However, we did not find an increased prevalence of positive TPOAb with age, whereas there is a marked increase in prevalence of elevated TSH values with age. These observations support the hypothesis that the autoimmune process starts at an earlier age, whereas the thyroid dysfunction is observed several years after the appearance of TPOAb. Mariotti et al. (35) have reported that thyroid function appears to be well preserved until the eighth decade of life in healthy subjects without changes in the TSH values, and they did not report differences in the prevalence of the presence of TPOAb with age.

The prevalence of positive TPOAb reported by different groups is difficult to compare because of the different assays used, no international standardisation of the assays and different cut-off values $(36,37)$. In this study we used a well documented assay system but set the cut-off value to $200 \mathrm{U} / \mathrm{ml}$ instead of $100 \mathrm{U} / \mathrm{ml}$ to be sure not to include those with weakly positive antibodies. Positive TPOAb were strongly correlated to thyroid dysfunction, and in our study even those with TSH values between 2 and $4 \mathrm{mU} / \mathrm{l}$ had a markedly increased percentage of positive TPOAb. The prevalence of elevated TSH was nearly 10-fold higher both in females and males with positive TPOAb compared with subjects with negative TPOAb. Vanderpump et al. (14) reported that, independent of age, the higher the serum level of TSH is above $2 \mathrm{mU} / \mathrm{l}$, the greater the prognostic significance for development of overt hypothyroidism in both TPOAb positive and negative subjects.

Both environmental and genetic factors are involved in the development of thyroid disorders. Except for iodine, the environmental determinants remain unknown. Evidence for genetic factors in the development of autoimmune thyroid disease has been demonstrated by clustering within families and in studies with twins $(38,39)$. Susceptibility genes or loci for autoimmune thyroid disease have not yet been identified (40).

The female : male ratios for previously diagnosed thyroid diseases were between 4.2 and 7.1, and 5.0 for positive TPOAb, whereas the female:male ratio of unrecognised hypothyroidism was surprisingly low (approximately 2). Thyroid dysfunction is known to be more common in females than in males, and females generally use the health care system more than males. It is important to recognise that thyroid disorders may be responsible for dysfunctions or illnesses also in males.

The clinical significance of positive TPOAb and/or subclinical hypo- or hyperfunction of the thyroid gland is not conclusive from the present study. The ongoing follow-up study in Nord-Trøndelag may hopefully provide answers.

\section{Acknowledgements}

We acknowledge the valuable financial support from Nycomed Pharma, Wallac and B.R.A.H.M.S. and also a scientific grant from Glaxo. The authors are grateful to Inger Gustafsson and the staff at the Hormone Laboratory, Aker University Hospital for their skilful technical assistance.

\section{References}

1 Tunbridge WM, Evered DC, Hall R, Appelton D, Brewis M, Clark F et al. The spectrum of thyroid disease in a community: the Wickham survey. Clinical Endocrinology 1977 7 481-493.

2 Sawin CT, Castelli WP, Hershman JM, McNamara, P \& Bacharach P. The aging thyroid. Thyroid deficiency in the Framingham study. Archives of Internal Medicine 1985145 1386-1388.

3 Canaris GJ, Manowitx NR, Mayor G \& Ridgway EC. The Colorado thyroid disease prevalence study. Archives of Internal Medicine $2000160526-534$.

4 Laurberg P, Pedersen KM, Vestergaard H \& Sigurdsson G. High incidence of multinodular toxic goitre in the elderly population in low iodine intake area vs. high incidence of Graves' disease in the young in a high iodine intake area: comparative surveys of thyrotoxicosis epidemiology in East-Jutland Denmark and Iceland. Journal of Internal Medicine 1991229 415-420.

5 Laurberg P, Pedersen KM, Hreidarsson A, Sigfusson N, Iversen E \& Knudsen PR. Iodine intake and the pattern of thyroid disorders: a comparative epidemiological study of thyroid abnormalities in the elderly in Iceland and in Jutland, Denmark. Journal of Clinical Endocrinlogy and Metabolism 199883 765-769.

6 Delang F. Disorders induced by iodine deficiency. Thyroid 19944 107-128.

7 Frey H, Rosenlund B \& Storli U. Urinary secretion of iodine in Norwegian population groups 1971-72. Tidsskrift for Den norske legeforening $197494982-987$.

8 Kapelrud H, Frey HM \& Theodorsen L. Urine iodine secretion. Tidsskrift for Den norske legeforening 1987115 1320-1321.

9 Norman N. The incidence of hyperthyroidism, hypothyroidism and diabetes in northern and southern Norway, a comparative study. Acta Medica Scandinavica 1955151.

10 Brochmann H, Bjøro T, Gaarder PI, Hanson F \& Frey HM. Prevalence of thyroid dysfunction in elderly subjects. Acta Endocrinologica 1989117 7-12.

11 Bjøro T, Frey HM, Larsen IF, Brochmann H, Hanson F \& Gaarder PI. Prevalence of thyroid dysfunction and thyroid antibodies in elderly subjects. Tidsskrift for Den norske lageforening 198910 1048-1051.

12 Sundbeck G, Lundberg P-A, Lindstedt G, Jagenburg R \& Edén S. Incidence and prevalence of thyroid disease in elderly women: results from the longitudinal population study of elderly people in Gothenburg, Sweden. Age and Ageing 199120 291-298. 
13 Petersen K, Lindstedt G, Lundberg P-A, Bengtson C, Lapidus L \& Nyström E. Thyroid disease in middle-aged and elderly Swedish women: thyroid-related hormones, thyroid dysfunction and goitre in relation to age and smoking. Journal of Internal Medicine 1991 229 407-414.

14 Vanderpump MPJ, Tunbridge WMG, French JM, Appleton D, Bates $\mathrm{D}$, Clark $\mathrm{F}$ et al. The incidence of thyroid disorders in the community: a twenty-year follow-up of the Wickham Survey. Clinical Endocrinology 199543 55-68.

15 Hak AE, Pols HAP, Visser TJ, Drexhage HA, Hofman A Witterman JCM. Subclinical hypothyroidism is an independent risk factor for atherosclerosis and myocardial infarction in elderly women: The Rotterdam study. Annals of Internal Medicine 2000 $132270-278$.

16 Rivolta G, Cerutti R, Colombo R, Miano G, Dionisio P \& Grossi E. Prevalence of subclinical hypothyroidism in a population living in the Milan metropolitan area. Journal of Endocrinological Investigation 199922 693-697.

17 Bauer DC \& Brown MD. Sensitive thyrotropin and free thyroxine testing in outpatients. Archives of Internal Medicine 1996156 2333-2337.

18 Sundick R, Bagchi N \& Brown TR. The role of iodine in thyroid autoimmunity: from chickens to humans: a review. Autoimmunity $19921361-68$

19 Sawin CT, Geller A, Wolf PA, Belanger AJ, Baker E, Bacharach P et al. Low serum thyrotropin concentrations as a risk factor for atrial fibrillation in older persons. New England Journal of Medicine $19943311249-1252$.

20 Presti CF \& Hart RG. Thyrotoxicosis, atrial fibrillation, and embolism, revisited. American Heart Journal $1989117976-977$.

21 Singer DE. Randomized trials of warfarin for atrial fibrillation. New England Journal of Medicine 1992327 1451-1453.

22 Staub JJ, Althaus BU, Engler H, Ryff AS, Trabucco P, Marquardt K et al. Spectrum of subclinical and overt hypothyroidism; effect on thyrotropin, prolactin, and thyroid reserve, and metabolic impact on peripheral target tissues. American Journal of Medicine 199292 631-642.

23 Kung AW, Pang RW \& Janus ED. Elevated serum lipoprotein (a) in subclinical hypothyroidism. Clinical Endocrinology $199543445-$ 449 .

24 Arem R \& Patsch W. Lipoprotein and apolipiprotein levels in subclinical hypothyroidism; effect of levothyroxine therapy. Archives of Internal Medicine 1990150 2097-2100.

25 Caron Ph, Calazei G, Parra HJ, Hoff M \& Louvet JP. Decreased HDL cholesterol in subclinical hypothyroidism; the effect of L-thyroxine therapy. Clinical Endocrinology 199033 519-523.

26 Bogner U, Arbtz H-R, Peters H \& Schleusener H. Subclinical hypothyroidism and hyperlipoproteinaemia: indiscriminate Lthyroxine treatment not justified. Acta Endocrinologica 1993128 202-206.

27 Diekman T, Lansberg PJ, Kastelein JJ \& Wiersienga WW. Prevelance and correction of hypothyroidism in a large cohort of patients referred for dyslilpidemia. Archives of Internal Medicine $19951551490-1495$.

28 Haggerty JJ Jr \& Prange AR Jr. Borderline hypothyroidism and depression. Annual Review of Medicine 199546 37-46.

29 Custro N, Scafidi V, LoBaido R, Nastri L, Abbate G, Gallo S et al. Subclinical hypothyroidism resulting from autoimmune thyroiditis in female patients with endogenous depression. Journal of Endocrinological Investigation 199417 641-646.

30 Joffe RT \& Levitt AJ. Major depression and subclinical (grade 2) hypothyroidism. Psychoneuroendocrinology 199217 215-221.

31 Nyström E, Caidahl, Fager G, Wikkelso C, Lundberg PA \& Lindstedt G. A double-blind cross-over 12-months study of L-thyroxine treatment of women with 'subclinical' hypothyroidism. Clinical Endocrinology $19882963-75$.

32 Holmen J, Midthjell K, Bjartveit K, Hjort PF, Lund-Larsen PF, Moum T et al. The Nord-Trøndelag Health Survey 1984-1986: Purpose, background and methods: Participation, nonparticipation and frequency distributions. Verdal, Norway, National Institute of Public Health 1990 (Report no. 4).

33 Midthjell K, Bjørndal A, Holmen J, Krüger Ø \& Bjartveit K. Prevalence of known and previously unknown diabetes mellitus and glucose intolerance in an adult Norwegian population: indications of an increasing diabetes prevalence: the NordTrøndelag Diabetes Study. Scandinavian Journal of Primary Health Care 199513 229-235.

34 Bjøro T, Gaarder PI, Smeland EB \& Kornstad L. Thyroid antibodies in blood donors: prevalence and clinical significance. Acta Endocrinologica $1984105324-329$.

35 Mariotti S, Barbesino G, Caturegli P, Bartalena L, Sansoni P, Fagnoni F et al. Complex alteration of thyroid function in healthy centanarians. Journal of Clinical Endocrinology and Metabolism $1993771130-1134$.

36 Feldt-Rasmussen U. Analytical and clinical performance goal for testing autoantibodies to thyroperoxidase, thyroglobulin, and thyrotropin receptor. Clinical Chemistry 199642 160-163.

37 Roti E, Gardini E, Minelli R, Bianconi L \& Braverman LE. Prevalence of anti-thyroid peroxidase antibodies in serum in the elderly: comparison with other tests for anti-thyroid antibodies. Clinical Chemistry 199238 88-92.

38 Bartels EJ. Heredity in Graves' disease. 1941 Copenhagen: Munksgaard.

39 Brix TH, Christensen K, Holm NV, Harvald B \& Hegedus L. A population-based study of Graves' disease in Danish twins. Clinical Endocrinology 199848 397-400.

40 Allahabadia A \& Gough SCI. The different approaches to the genetic analysis of autoimmune thyroid disease. Journal of Endocrinology $19991637-13$.

Received 13 April 2000

Accepted 19 June 2000 